Indonesian Science Education Research
(ISER)

\title{
THE EFFECT OF THE USE OF VIDEO-BASED LEARNING MEDIA LIGHT AND OPTICAL TOOLS ON THE IMPROVEMENT OF STUDENTS 'LEARNING OUTCOMES
}

\author{
Simanullang, M. Y., Simanjuntak, P. R. N. \\ Department of Science Education, Faculty of Mathematics and Natural Science, Universitas \\ Negeri Medan \\ meirandasimanullang@mhs.unimed.ac.id
}

Accepted: May 10th, 2021. Published: September 6th, 2021

\begin{abstract}
This study aims see the use of instructional video media on student learning outcomes in the subject of light and optical tools for junior high school students with a random sample of grade eight junior high school students and online methods. The object of this research was students learning outcomes. Data collection techniques used test techniques through the Google form application. Quantitative data analysis techniques used in the form of test scores for student cognitive learning outcomes. The Test Instrument contains 20 multiple choice questions. The results showed that the video media was suitable for use with the "good" category as a learning medium for students.
\end{abstract}

Keywords: Instructional videos, Instructional media, Learning outcomes 


\section{Introduction}

Education has a very important role in efforts to build and educate the nation. This effort depends on one of the determinants in its realization, namely the teacher. Teachers are required to be able to convey and present learning to students with various methods, interesting and innovative media so that students can accept applying them in their lives as provisions for the future.

In the current era of globalization, the development of technology and information greatly helps the development of education. Technology becomes a place to present learning to students in an interesting and unlimited way. Conventional learning that only relies on teachers and printed books has begun to decline due to better adjustments. In this connection, teachers are required to be able to master technology in order to make it easier for students to learn. The technology is then utilized by the media as a place for applying learning to students.

Good learning media are media that are innovative, interesting, inspiring and informative. Learning media consists of various kinds. One of them is in the form of video. Video is an audio-visual media that has been in great demand and utilized by the community in all aspects of life. The role of video in the educational aspect is very helpful considering the advantages of the video itself, as stated by Bavarharji, Alavi, and Letchumanan (2014) that "The results showed that the effects of viewing captioned instructional videos are greater on vocabulary acquisition and language proficiency development than on content comprehension ". From this statement, it can be concluded that the use of video can improve students' grammar skills which make it easier to understand the material.

Science learning that should be done is learning that can prepare students to be literate in science and technology, able to think logically, critically and creatively (Galuh Rahayuni, 2016). Instructional videos are very appropriate to use in science learning, especially in light material and optical devices, because this material has a number of application examples and depiction steps that are difficult to describe if only with explanations alone. Therefore, it will be very easy for students to accept if they can see it in a clear and attractive visual form.

The implementation of learning cannot be separated from the assessment of learning outcomes. There are many online applications that can be used in educational assessments, including google form (Mulatsih, 2020).

According to Nana Sudjana (2016) "Learning outcomes are the abilities students have after receiving their learning experiences". Learning in which students are only required to pay attention to the explanation of the material delivered by the teacher without the involvement of students to be active in asking, responding to material, interacting and expressing opinions will be able to affect student learning outcomes. Therefore, learning media are needed to achieve the desired results through tools or media.

Based on the above problems, as for the formulation of the problem in this study, how is the effect of video learning media with light material and optical tools on improving junior high school student learning outcomes?

\section{Research Method}

When this research was conducted on December 29, 2020. The research was conducted online through social media and applications such as Whatsapp, and Google forms.Respondents in this study were 16 junior high school students randomly. The technique used in data collection is the test technique.

The test technique was used to collect data on student learning outcomes consisting of 20 pre-test and post-test items which were published on the google form. Quantitative data analysis techniques in the form of assessment scores on student cognitive learning outcomes. each valid question is worth 5 points.

Furthermore, based on cognitive learning outcomes, the value obtained by students is calculated using the assessment formula as follows: 


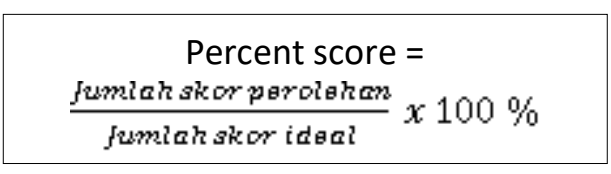

The data and scores generated from the tests are then categorized in Table 1 as the following assessment criteria.

Table 1. Assessment criteria

\begin{tabular}{c|c|c}
\hline Score interval & $\begin{array}{c}\text { Scor } \\
\text { e }\end{array}$ & Category \\
\hline $90-100$ & A & Very good \\
\hline $80-89$ & B & Good \\
\hline $75-79$ & C & Enough \\
\hline$<75$ & D & less \\
\hline
\end{tabular}

After the value is obtained, it is compared with the Minimum Completeness Criteria (KKM), which is 70 . Students are said to be complete if they get a minimum score of 70 .

\section{Result and Discussion \\ Preliminary studies}

Learning video media with light material and optical tools was developed on the basis of development tailored to the needs of a medium that mable to make it easier for students to understand the material. The information was collected by observing the pretest and posttest questions about the students' cognitive learning outcomes as many as 20 items each.

\section{Assessment Data on Cognitive Learning Outcomes}

The pretest will be given to students first before the instructional video media to see the students' initial abilities. The pretest results are then categorized as very good for A, Good for B, Enough for C, Less for D with the criteria as in table 1 . Prestest and posttest are 20 items each. Each item has a value of 5 points.

\section{Cognitive Learning Outcomes Test Prestest}

The initial activity in this learning is in the form of giving pretest questions as many as 20 items to see the students' initial learning ability regarding the material of light and known optical devices. Subjects in this initial trial were 16 students as respondents. the results of cognitive learning tests in the initial trials as in Table 2.

Table 2. Student Cognitive Learning Outcomes Test Initial Trial Pretest

\begin{tabular}{|c|c|c|c|}
\hline No. & Students & Score & Information \\
\hline 1 & VVN & 45 & Not finished yet \\
\hline 2 & IRN & 50 & Not finished yet \\
\hline 3 & PRS & 10 & Not finished yet \\
\hline 4 & PJ & 80 & Completed \\
\hline 5 & IJ & 15 & Not finished yet \\
\hline 6 & ADR & 10 & Not finished yet \\
\hline 7 & FDL & 15 & Not finished yet \\
\hline 8 & TLR & 80 & Completed \\
\hline 9 & JFN & 70 & Completed \\
\hline 10 & $\mathrm{TH}$ & 70 & Completed \\
\hline 11 & FNY & 70 & Completed \\
\hline 12 & SRH & 80 & Completed \\
\hline 13 & $\mathrm{CH}$ & 65 & Not finished yet \\
\hline 14 & LL & 70 & Completed \\
\hline 15 & CSS & 80 & Completed \\
\hline \multirow[t]{5}{*}{16} & MRA & 7 & Completed \\
\hline & total & 885 & \\
\hline & Average & 55.3 & \\
\hline & $\begin{array}{l}\text { The highest } \\
\text { score }\end{array}$ & 80 & \\
\hline & Lowest score & 10 & \\
\hline
\end{tabular}

Based on Table 3, it is known that there are 9 students who get complete grades with grades $\geq 70$. Meanwhile, 7 other students obtained scores that had not been completed with grades. The average score of the 16 students was $55.3 . \geq 10$

\section{Student Response Scale} Prestest 
After converting to a scale of 4, Furthermore, the scores that have been obtained from the pretest are processed to know the values and criteria using the assessment criteria scale in table 1.The following is the student response scale data in the initial trial:

Table 3. the results of calculating the Student Response Scale in the Preliminary Trial.

\begin{tabular}{|c|c|c|c|c|}
\hline No. & Students & Score & Score & $\begin{array}{l}\text { Criteri } \\
\text { a }\end{array}$ \\
\hline 1 & VVN & 45 & $\mathrm{D}$ & less \\
\hline 2 & IRN & 50 & $\mathrm{D}$ & less \\
\hline 3 & PRS & 10 & $\mathrm{D}$ & less \\
\hline 4 & PJ & 80 & B & Good \\
\hline 5 & IJ & 15 & $\mathrm{D}$ & less \\
\hline 6 & ADR & 10 & $\mathrm{D}$ & less \\
\hline 7 & FDL & 15 & $\mathrm{D}$ & less \\
\hline 8 & TLR & 80 & B & Good \\
\hline 9 & JFN & 70 & $\mathrm{D}$ & less \\
\hline 10 & $\mathrm{TH}$ & 70 & $\mathrm{D}$ & less \\
\hline 11 & FNY & 70 & $\mathrm{D}$ & less \\
\hline 12 & SRH & 80 & B & Good \\
\hline 13 & $\mathrm{CH}$ & 65 & $\mathrm{D}$ & less \\
\hline 14 & $\mathrm{LL}$ & 70 & $\mathrm{D}$ & less \\
\hline 15 & CSS & 80 & B & Good \\
\hline \multirow[t]{5}{*}{16} & MRA & 75 & $\mathrm{C}$ & $\begin{array}{l}\text { Enoug } \\
\mathrm{h}\end{array}$ \\
\hline & total & 885 & & \\
\hline & Average & 55.3 & & \\
\hline & $\begin{array}{l}\text { The } \\
\text { highest } \\
\text { score }\end{array}$ & 80 & & \\
\hline & $\begin{array}{l}\text { Lowest } \\
\text { score }\end{array}$ & 10 & & \\
\hline
\end{tabular}

Based on the results of student responses in Table 5, it can be seen that there are 11 students with poor criteria, 1 student enough criteria and 4 students in the Good criteria.

\section{Cognitive Learning Outcomes Test}

Postest

The final activity in learning is the evaluation of student learning outcomes. This evaluation aims to determine the ability of students to understand and accept the material that has been studied and watched through the learning videos that have been given. The subjects in this test were 16 students. The following is table 4. Student Cognitive Learning Outcomes from student evaluation tests

Table 4. Student Cognitive Learning Outcomes from student evaluation tests

\begin{tabular}{|c|c|c|c|}
\hline No. & Students & Score & Information \\
\hline 1 & VVN & 50 & Not finished yet \\
\hline 2 & IRN & 55 & Not finished yet \\
\hline 3 & PRS & 20 & Not finished yet \\
\hline 4 & PJ & 85 & Completed \\
\hline 5 & IJ & 70 & Completed \\
\hline 6 & ADR & 75 & Completed \\
\hline 7 & FDL & 25 & Not finished yet \\
\hline 8 & TLR & 80 & Completed \\
\hline 9 & JFN & 70 & Completed \\
\hline 10 & TH & 75 & Completed \\
\hline 11 & FNY & 80 & Completed \\
\hline 12 & $\mathrm{SRH}$ & 85 & Completed \\
\hline 13 & $\mathrm{CH}$ & 70 & Completed \\
\hline 14 & LL & 75 & Completed \\
\hline 15 & CSS & 85 & Completed \\
\hline \multirow[t]{5}{*}{16} & MRA & 80 & Completed \\
\hline & total & 1080 & \\
\hline & Average & 67.5 & \\
\hline & $\begin{array}{l}\text { The highest } \\
\text { score }\end{array}$ & 85 & \\
\hline & $\begin{array}{l}\text { Lowest } \\
\text { score }\end{array}$ & 20 & \\
\hline
\end{tabular}

Based on the table, there is a change in the criteria compared to the Preliminary 
Trial in table 3 . There are 4 students with incomplete criteria and 12 students with Completed criteria.

\section{Student Response Scale \\ Postest}

The student response scale consists of two specs such as the response to the initial trial. The student response scale was given to the same 16 students to see the effect of the learning video media that light and optical tools had been watched, then processed using the basis of the student response scale conversion as in table 5.The results of calculating the student response scale in the following student evaluation test:

Table 5. Results of Calculating Student Response Scale on Student Evaluation Test

\begin{tabular}{|c|c|c|c|c|}
\hline No. & Students & Score & Score & Criteria \\
\hline 1 & VVN & 50 & $\mathrm{D}$ & less \\
\hline 2 & IRN & 55 & $\mathrm{D}$ & less \\
\hline 3 & PRS & 20 & $\mathrm{D}$ & less \\
\hline 4 & PJ & 85 & B & Good \\
\hline 5 & IJ & 70 & $\mathrm{D}$ & less \\
\hline 6 & ADR & 75 & $\mathrm{C}$ & Enough \\
\hline 7 & FDL & 25 & $\mathrm{D}$ & less \\
\hline 8 & TLR & 80 & B & Good \\
\hline 9 & JFN & 70 & $\mathrm{D}$ & less \\
\hline 10 & TH & 75 & $\mathrm{C}$ & enough \\
\hline 11 & FNY & 80 & B & Good \\
\hline 12 & SRH & 85 & B & Good \\
\hline 13 & $\mathrm{CH}$ & 70 & $\mathrm{D}$ & less \\
\hline 14 & LL & 75 & $\mathrm{C}$ & Enough \\
\hline 15 & CSS & 85 & B & Good \\
\hline \multirow[t]{5}{*}{16} & MRA & 80 & B & Good \\
\hline & total & 1080 & & \\
\hline & Average & 67.5 & & \\
\hline & $\begin{array}{l}\text { The highest } \\
\text { score }\end{array}$ & 85 & & \\
\hline & $\begin{array}{l}\text { Lowest } \\
\text { score }\end{array}$ & 20 & & \\
\hline
\end{tabular}

Based on table 5, it is known that the average score of students' cognitive results is 67.5. Students with less criteria are 7 students. Students with sufficient criteria are 3 students with good criteria A total of 6 students.

Recapitulation of Student Cognitive Learning Outcomes Test Results

Cognitive learning outcomes are part of an aspect in improving learning video media. Based on the results of the data tested, you can get the prestest and postest data. The results of the pretest and posttest can be seen in table 6 below:

Table 6. Results of the Recapitulation of the Pretest and Postest of Cognitive Learning Outcomes.

\begin{tabular}{llll}
\hline \multirow{2}{*}{$\begin{array}{l}\text { No. } \\
\text { (KKM 70) }\end{array}$} & \multicolumn{2}{c}{ Type of Test } \\
\cline { 3 - 4 } & & Pretest & Postest \\
\hline 1 & Completed & 9 & 12 \\
\hline 2 & Not complete & 7 & 4 \\
\hline & total & 885 & 1080 \\
\hline & Average & 55.3 & 67.5 \\
\hline & $\begin{array}{l}\text { The highest } \\
\text { score }\end{array}$ & 80 & 85 \\
\hline & & \\
\hline & Lowest Value & 10 & 20 \\
\hline
\end{tabular}

Based on table 6, it is known that there is an increase in the number of students with a complete score of 3 students. the number also increased by 195 points. The students' mean score also increased by 12.2 points. The highest score has increased by 5 points and the lowest score has increased by 10 points. Video media is given to see the increase in student learning outcomes itself using a postest with the same questions so that it can be compared to changes in the scores obtained by students. The following is a summary of cognitive learning outcomes presented in diagrammatic form: 


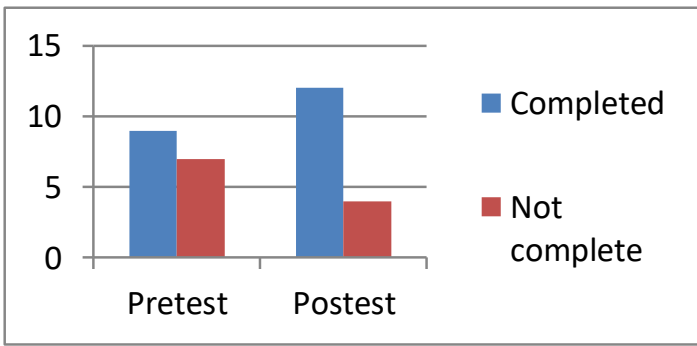

Diagram 1. Assessment of students' prestest and postest cognitive learning outcomes

\section{Results of student response notes}

Recorded student responses were also obtained to see the criteria for the value obtained by students through the prestest and posttest which were given as many as 20 questions which were the same as the student's cognitive learning outcomes. The following are the results of student response summaries in table 7.

Table 7. Calculation Results of Student Response Scale

\begin{tabular}{llll}
\hline No. & Criteria & \multicolumn{2}{c}{ Type of Test } \\
\cline { 3 - 4 } & & Pretest & Postest \\
\hline 1 & Very good & - & - \\
\hline 2 & Good & 4 & 6 \\
\hline 3 & Enough & 1 & 3 \\
\hline 4 & Less & 11 & 7 \\
\hline & total & 885 & 1080 \\
\hline & Average & 55.3 & 67.5 \\
\hline & The highest & 80 & 85 \\
\hline & & & \\
\hline & Lcore & 10 & 20 \\
\hline
\end{tabular}

Based on table 7 Not found students with very good criteria, but for good and sufficient categories, it was found that 2 students increased the number of scores from prestest to postest with Good criteria. enough criteria as many as 2 students and criteria for less decreased by 4 students. The following are the results of student response summaries presented in diagrammatic form:

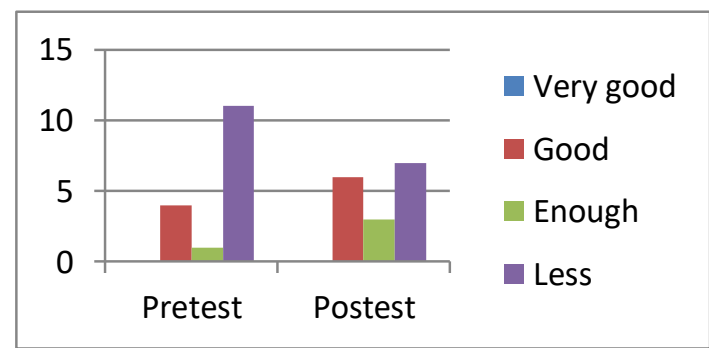

Diagram 2. Assessment of Results Summary of students' pretest and posttest responses

\section{Conclusion}

Based on the research that has been done, it can be concluded that there is an effect of increasing student learning outcomes using video learning media with light material and optical tools to students. this increase in learning outcomes is the criterion of "good".

\section{Reference}

Bavaharji, M., Alavi, ZK, \& Letchumanan, K. (2014). Captioned instructional video: effects on content comprehension vocabulary acquisition and language proficiency. Canadian Center of Science and Education, 7, 1-16.

Galuh Rahayuni. 2016. The Relationship of Critical Thinking Skills and Scientific Literacy in Integrated Science Learning with PBM and STM Models, JPPI 2 (2), 131-146.

Mulatsih, B. 2020. Application of Google Classroom, Google Form, and Quizizz in Chemistry Learning in Mada Covid-19 Pandemic. Journal of Teacher's Scientific Work: Vol. 5 (1): 16-16.

Nana Sudjana. 2016. Assessment of Teaching and Learning Process Results. Bandung: PT Remaja Rosdakarya. 